Lisbon - Malacca Port Cities Twin Conferences 2019 / 2020

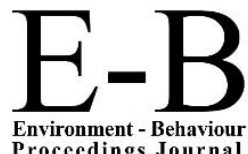
Environment - Behaviour
Proceedings Journal
AicQoL2020Malacca

ASLI (Annual Serial Landmark International) Conferences on QoL2020

https://www.amerabra.org; https://fspu.uitm.edu.my/cebs; https://www.emasemasresources.com/

8th AMER International Conference on Quality of Life

Mahkota Hotel Melaka, Malacca, Malaysia, 18-19 Mar 2020

(Due to the Covid-19 lockdown, paper virtually presented on 25 Mar 2020)

\title{
Human and Animals Conflicts: A case study of wildlife roadkill in Malaysia
}

\author{
Norhafezah Kasmuri ${ }^{1}$, Nadirah Nazar , Abdullah Zawawi Mohd Yazid ${ }^{2}$ \\ 1 Faculty of Civil Engineering, \\ Universiti Teknologi MARA, Shah Alam, Selangor, Malaysia \\ 2 Department of Wildlife and National Parks (PERHILITAN), \\ KM 10, Jalan Cheras 56100 Kuala Lumpur, Malaysia
}

norhafezahkasmuri@uitm.edu.my, nazarnadirah@gmail.com, zawawi@wildlife.gov.my

Tel: 603-55436482

\begin{abstract}
Conflicts between humans and animals have been a challenge due to rapid urbanization. Most of the forest is cleared to build roads and highway. Thus, animals need to migrate or move for their survival. This paper aims to review wildlife roadkill data from PERHILITAN and arranged it under several groups of species. Here, quantitative analysis of the roadkill data is used to select one species as the primary subject (Malayan Tapir). It has been observed that Malayan Tapir has involved in 68 vehicle collisions with a total loss of RM6.8 million in 5 years. From these results, long-term mitigation measures have been addressed in this study.
\end{abstract}

Keywords: human; road construction; wildlife roadkill; mitigation

eISSN: 2398-4287 @ 2020. The Authors. Published for AMER ABRA cE-Bs by e-International Publishing House, Ltd., UK. This is an open access article under the CC BYNC-ND license (http://creativecommons.org/licenses/by-nc-nd/4.0/). Peer-review under responsibility of AMER (Association of Malaysian Environment-Behaviour Researchers), ABRA (Association of Behavioural Researchers on Asians) and cE-Bs (Centre for Environment-Behaviour Studies), Faculty of Architecture, Planning \& Surveying, Universiti Teknologi MARA, Malaysia.

DOI: https://doi.org/10.21834/e-bpj.v5i13.2093

\subsection{Introduction}

The fast development planning for the overall economic and social expansion of the country makes Malaysia become a more productive country. The infrastructure, especially roads and highways are convenient for the public to commute from one place to another place in short or long distances. The facilities provided have encouraged the citizens of Malaysia to do their various types of business and economic activities. Hence, the result of the rapid development planning in Malaysia has made the country gained proper progress and greater success in economic growth and productivity.

However, the rapid urbanization of Malaysia in urban and sub-urban areas has significantly impacted the surrounding environment. Here, deforestation is a must to build roads and the highway. During the construction of this infrastructure, trees need to be cut as land is cleared to ensure the road and highway can be built. Thus, this creates conflict between humans and animals as the wildlife's habitat is gone and they are forced to migrate for their survival. This wildlife needs to find their necessities such as food source, water and shelter. This condition has dramatically reduced the quality of ecology and ecosystem services. If the situation prolongs, Malaysia is facing a severe problem with species extinction.

Furthermore, certain species can be found only in Malaysia's forest (WWF, 2018), which is valuable to the country. Road, while central to the function of human society, create barriers to animal movement through collisions and habitat fragmentation. Barriers to animal movement affect the evolution and trajectory of populations (Jacobson et al., 2016). Even though the quality of life for humans

eISSN: 2398-4287 @ 2020. The Authors. Published for AMER ABRA cE-Bs by e-International Publishing House, Ltd., UK. This is an open access article under the CC BYNC-ND license (http://creativecommons.org/licenses/by-nc-nd/4.0/. Peer-review under responsibility of AMER (Association of Malaysian Environment-Behaviour Researchers), ABRA (Association of Behavioural Researchers on Asians) and cE-Bs (Centre for Environment-Behaviour Studies), Faculty of Architecture, Planning \& Surveying, Universiti Teknologi MARA, Malaysia.

DOI: https://doi.org/10.21834/e-bpj.v5i13.2093 
is upgraded due to road construction, this contrasts with the wildlife. Here, this animal's existence is denied from the result of infrastructure development towards the economic expansion of the country (Sodhi et al., 2010).

\subsection{Malaysia's Transportation System}

Transportation infrastructure affects the structure of ecosystems, the dynamics of ecosystem function, and has direct effects on ecosystem components, including their species composition. The construction of transport lines results in the direct destruction and removal of existing ecosystems and the reconfiguration of local landforms (Coffin, 2007). Here is a lesson learned that not only humans should require to travel from one place to another to achieve specific purposes, but so do the wildlife's migrating for their purpose too. This whole situation is a disaster to the wildlife habitat, ecology system and diminishing the species for the overall 'resident' that living together in the tropical forests ecosystem.

Tropical forests are highly diverse systems involving extraordinary numbers of interactions between species, with each species responding in a different way to the abiotic environment. Understanding how these systems function and predicting their response to anthropogenic global change is extremely challenging (Fayle et al., 2015). The tropical forest ecosystems are highly complex and heterogeneous, comprising diverse networks of interactions between those communities and the environment. The knowledge of ecosystem services is vital. Here, the function, including carbon sequestration, climate regulation, and supply of water and conservation of biodiversity, need to be further understood (Fayle et al., 2015).

After World War II, Malaysia has achieved independence from the British, and from that, Malaysia has continued to gain pride in developing and fast-growth countries until today. However, due to all modernization, development and business, we tend to forget that our natural resources had been 'depleted' day by day. This decrease of natural resources, including land, forest, flora and fauna and freshwater in a few years ahead, would impact the quality of life for humans and wildlife significantly. From this scenario, it is crucial to sustaining our natural assets as this resource is valuable for us and our future generation. Environmental ethics on human relationships with the environment is vital for a sustainable ecosystem.

In line with Sustainable Development Goals 11 (to make cities and human settlements inclusive, safe, resilient and sustainable) by 2030, people need to reduce the adverse per capita environmental impact of cities to the surroundings (Pradhan, et al., 2017). From here, Malaysia continues to strive to boost its economy in line with getting profit from the development of road, infrastructure, buildings and housing. However, the implementation of sustainable pillars (environment, economy and social) imbedded in green structure would reduce the adverse impact on the environment. Best management practice in the construction phase until the execution of the project would significantly lessen the detrimental effect on the environment. Thus, could reduce the human-animal conflict as the green structure could assimilate as a part of the urban forest and can be replaced as habitat or niche for these animals (Ahmad Zafir and Magintan, 2016).

\subsection{Significant of Study}

This research paper is to highlight the problem faced by wildlife because Malaysia's road and transportation development have endangered them. However, the efforts from the Malaysian government for the development of transportation infrastructure need to be praised. The problem is that the way of doing it is less sustainable. Easy excess from the construction of road and highways are giving benefits to human and society. Unfortunately, this situation creates losses in wildlife in many ways. This structure would demolish the habitat of wildlife and forced them to migrate from one place to another for survival.

\subsection{Aim and Objective}

The aim of this research is focused on wildlife roadkill as each wildlife species has its price value in the ecosystem services, which can be regarded as an asset to Malaysia. Here, the review wildlife roadkill data from PERHILITAN has been arranged into its groups of species. Then the selection of one species and their number of collisions are determined in the price of monies, Ringgit Malaysia (RM). Later, the long-term mitigation method was suggested.

\subsection{Literature Review}

There is an existence of illegal trade and poaching involving wildlife due to the value of these animals such as Malay Tiger, Elephant, Tapir and many more are achieving millions of Ringgit Malaysia in higher demand. This problem has already caused the extinction of these species (WWF, 2018; Brown, 2017). The situation between humans and wildlife is an imbalance where we are enjoying the road facilities, but other creatures are suffering due to their habitat loss. A further difficulty arises facing the wildlife due to fragmentation of forest, ecosystem disturbance and species extinction. Here, the problem of animal roadkill is neglected as too many loopholes in the issue of their necessities. The death of animals due to road accidents is a significant loss to the country. The mistakes are lying at how the development process had being carried out. In getting the balance of human and wildlife needs, the change of methods in carrying out the development process would be necessary from a conventional system to a more sustainable approach.

\subsection{Wildlife Crossings in Malaysia}

The fragmentation of Peninsular Malaysia Tropical Forest from 1900 to 1990 due to urbanization has created diversity in animals' populations and habitats (UNDP, 2013). An experimental approach to road mitigation that maximizes inferential power is essential to ensure that mitigation is both ecologically successful and cost-effective (Rytwinski et al., 2015). In Malaysia, several initiatives from the 
Malaysian government has been apprehended to mitigate the issues of wildlife. Several wildlife crossings have been considered and built, as shown in Table 1. This wildlife crossing is to reduce road and highway implications and facilitating the migration of these animals.

Here, eco-viaduct no.3 at Sungai Yu is the most extended (900m long) wildlife crossing structure ever built in Malaysia and South East Asia (JKR, 2015). The Malaysia Public Work Department built three eco-viaducts with the Department of Wildlife and National Parks Peninsular Malaysia (PERHILITAN) in the two corridor locations at Sungai Deka, Terengganu, and Sungai Yu, Pahang. The third eco-viaduct was built at Gerik, Perak, on Corridor Ecology of Central Forest Spine (CFS) built by Empayar Kukuh Sdn Bhd (Contractor), Perunding HJRS Sdn Bhd (Consultant) and Forestry Department Peninsular Malaysia (Client) (DURA Technology Sdn Bhd, 2014).

Table 1. Wildlife Crossings in Malaysia

\begin{tabular}{ccccccc}
\hline No & Type & Name & Location & X Grid & Y Grid & Length (m) \\
\hline 1 & Underpass Viaduct & 1 & Hulu Terengganu & 502793 & 553193 & 245 \\
2 & Underpass Viaduct & 2 & Hulu Terengganu & 504707 & 554963 & 140 \\
3 & Underpass Viaduct & 3 & Hulu Terengganu & 507758 & 556506 & 245 \\
4 & Underpass Viaduct & Sg Yu 1 & Kuala Lipis, Pahang & 444022 & 505113 & 80 \\
5 & Underpass Viaduct & Sg Yu 2 & Kuala Lipis, Pahang & 443867 & 504679 & 250 \\
6 & Underpass Viaduct & Sg Yu 3 & Kuala Lipis, Pahang & 443705 & 502908 \\
7 & Underpass Viaduct & Belum & Hulu Perak, Perak & 388060 & 618169 & 900 \\
8 & Overpass Crossing & N/A & Seremban, N9 & 436474 & 295033 \\
9 & Overpass Crossing & N/A & Port Dickson, N9 & 429862 & 278345 \\
10 & Underpass Crossing & M1 & Hulu Perak, Perak & 327169 & 610772 & 200 \\
11 & Underpass Crossing & M10 & Hulu Perak, Perak & 342843 & 605609 & N/A \\
12 & Underpass Crossing & M11 & Hulu Perak, Perak & 347069 & 603042 & 200 \\
13 & Underpass Crossing & M2 & Hulu Perak, Perak & 327721 & 609136 \\
14 & Underpass Crossing & M3 & Hulu Perak, Perak & 329637 & 608863 \\
15 & Underpass Crossing & M4 & Hulu Perak, Perak & 331463 & 608390 \\
16 & Underpass Crossing & M5 & Hulu Perak, Perak & 333346 & 609223 \\
17 & Underpass Crossing & M6 & Hulu Perak, Perak & 333738 & 609517 \\
18 & Underpass Crossing & M7 & Hulu Perak, Perak & 334218 & 609381 \\
19 & Underpass Crossing & M8 & Hulu Perak, Perak & 334954 & 608539 \\
20 & Underpass Crossing & M9 & Hulu Perak, Perak & 339403 & 608361 & 200 \\
\end{tabular}

(Source: PERHILITAN, 2018)

\subsection{Wildlife -Vehicle Collision}

Despite the existence of wildlife crossing, cases of animal roadkill keep on increasing over the years. Data provided by PERHILITAN has shown that the death of animals recorded was 2,444 from the year 2012 until 2017. Table 2 listed the number of animals involved with the vehicle collision. The data collected from PERHILITAN can impose mitigation measures for the existing structures for further sustainability on ecosystem valuation. Besides, the analysis of data from animals' roadkill is determined quantitatively for further development of green structure in Malaysia.

Table 2. Wildlife Roadkill Data Recorded from 2012 to 2017

\begin{tabular}{|c|c|c|c|c|}
\hline No & NDX & English Name & Scientific Name & Quantity \\
\hline 1 & Mammals & Asiatic wild dog & Cuon alpinus & 1 \\
\hline 2 & Mammals & Malayan Sun Bear & Helarctos malayanus & 6 \\
\hline 3 & Mammals & Pig-tailed Macaque & Macaca nemestrina & 9 \\
\hline 4 & Mammals & Binturong & Arctictis binturong & 8 \\
\hline 5 & Mammals & Wild Boar & Sus scrofa & 265 \\
\hline \multirow[t]{2}{*}{6} & Mammals & Crab-eating Mongoose & Herpestes urva & 21 \\
\hline & & Small Indian Mongoose & Herpestes javanicus & 2 \\
\hline 7 & Mammals & Asian Elephant & Elephas maximus & 4 \\
\hline \multirow[t]{2}{*}{8} & Mammals & Malayan Tiger & Panthera tigris & 1 \\
\hline & & Leopard & Phantera pardos & 2 \\
\hline 9 & Mammals & Leopard Cat & Prionailurus bengalensis & 88 \\
\hline 10 & Mammals & Serrow & Capricornis sumatraensis & 2 \\
\hline 11 & Mammals & Long-tailed Macaque & Macaca fascicularis & 439 \\
\hline 12 & Mammals & Slow Loris & Nycticebus coucang & 1 \\
\hline 13 & Mammals & Malayan Porcupine & Hystrix brachyura & 9 \\
\hline \multirow[t]{5}{*}{14} & Mammals & Silvered Leaf Monkey & Presbytis cristatus & 1 \\
\hline & & Mitred Leaf Monkey & Presbytis melalophos & 6 \\
\hline & & Leaf-monkey & Presbytis sp. & 1 \\
\hline & & Silvered Leaf Monkey & Trachyopithecus cristatus & 1 \\
\hline & & Dusky Leaf Monkey & Trachypithecus obscurus & 18 \\
\hline \multirow[t]{4}{*}{15} & Mammals & Small-clawed otter & Aonyx cinerea & 3 \\
\hline & & Otter & Lutra spp. & 11 \\
\hline & & Hairy-nosed Otter & Lutra sumatrana & 3 \\
\hline & & Smooth Otter & Lutrogale perspicillata & 5 \\
\hline 16 & Mammals & Yellow-throated Marten & Martes flavigula & 1 \\
\hline
\end{tabular}




\begin{tabular}{|c|c|c|c|c|}
\hline No & NDX & English Name & Scientific Name & Quantity \\
\hline 17 & Mammals & Civet & Family Viverridea & 2 \\
\hline & & Common Palm Civet & Paradoxurus Hermaphroditus & 418 \\
\hline & & Malayan Civet & Viverra tangalunga & 20 \\
\hline & & Large Indian Civet & Viverra zibetha & 6 \\
\hline 18 & Mammals & Sambar Deer & Rusa unicolor & 1 \\
\hline 19 & Mammals & Malayan Tapir & Tapirus indicus & 68 \\
\hline 20 & Mammals & Pangolin & Manis javanica & 4 \\
\hline 21 & Mammals & Moonrat & Echinosorex gymnura & 3 \\
\hline \multirow[t]{4}{*}{22} & Mammals & Plantain Squirrel & Callosciurus notatus & 3 \\
\hline & & Oriental Tree Squirrels & Callosciurus prevostii & 1 \\
\hline & & Cream-coloured Giant Squirrel & Ratufa affinis & 1 \\
\hline & & Black Giant Squirrel & Ratufa bicolor & 8 \\
\hline \multirow[t]{2}{*}{23} & Reptile & Clouded Monitor & Varanus bengalensis & 23 \\
\hline & & Water Monitor Lizard & Varanus salvator & 742 \\
\hline 24 & Reptile & Malayan Box Turtle & Cuora amboinensis & 1 \\
\hline \multirow[t]{2}{*}{25} & Reptile & Malayan pit viper & Calloselasma rhodostoma & 7 \\
\hline & & Viper & Viperidae & 2 \\
\hline \multirow[t]{2}{*}{26} & Reptile & Reticulated python & Python Reticulatus & 59 \\
\hline & & Blood Python & Python curtus & 1 \\
\hline 27 & Reptile & King Cobra & Ophiophagus Hannah & 16 \\
\hline \multirow[t]{2}{*}{28} & & Monocellate Cobra & Naja kaouthia & 40 \\
\hline & & Equatorial Spitting Cobra & Naja sumatrana & 2 \\
\hline \multirow[t]{2}{*}{29} & Reptile & Rat Snake & Ptyas spp. & 4 \\
\hline & & Indo-Chinese Rat snake & Pytas korros & 1 \\
\hline 30 & Reptile & Dog-toothed Cat Snake & Boiga cynodon & 2 \\
\hline Miscellaneous & & Mangrove cat snake & Boiga dendrophila & 1 \\
\hline \multirow[t]{6}{*}{ Snakes } & & Malayan Krait & Bungarus candidus & 3 \\
\hline & & Common Malayan Racer & Coelognathus flavolineata & 1 \\
\hline & & Radiated Ratsnake & Coelognathus radiata & 3 \\
\hline & & Cave Dwelling Snake & Elaphe taeniura & 2 \\
\hline & & Snake & Suborder Serpentes & 2 \\
\hline & & Cave Racer & - & 1 \\
\hline 31 & Bird & Red Junglefowl & Gallus gallus & 12 \\
\hline \multirow[t]{4}{*}{32} & Bird & Owl & Family Strigidae & 3 \\
\hline & & Barn Owl & Tyto alba & 16 \\
\hline & & Buffy Fish-owl & Ketupa ketupu & 9 \\
\hline & & Spotted Wood-Owl & Strix seloputo & 2 \\
\hline \multirow[t]{2}{*}{33} & Bird & Japanese Sparrowhawk & Accipiter gularis & 1 \\
\hline & & Eaqle & & 3 \\
\hline 34 & Bird & White-breasted Waterhen & Amaurornis phoenicurus & 19 \\
\hline 35 & Bird & Yellow bittern & - & 1 \\
\hline Miscellaneous & & Common Myna & Acridotheres tristis & 7 \\
\hline \multirow[t]{8}{*}{ Birds } & & Oriental Pied Hornbill & Anthracoceros albirostris & 1 \\
\hline & & Greater Coucal & Centropus sinensis & 7 \\
\hline & & Slaty-breasted Rail & Gallirallus striatus & 1 \\
\hline & & White-Throated Kingfisher & Halcyon smyrnensis & 1 \\
\hline & & Lesser Adjutant & Leptoptilos javanicus & 1 \\
\hline & & Black Naped Oriole & Oriolus chinensis & 3 \\
\hline & & Stork-billed Kingfisher & Pelargopsis capensis & 1 \\
\hline & & & TOTAL & 2444 \\
\hline
\end{tabular}

(Source: PERHILITAN, 2018)

\subsection{Methodology}

Based on PERHILITAN data of the 2444 wildlife roadkill from the year 2012 to 2017, the result has been arranged for the quantity of roadkill for each species. The objective of this calculation is to select one species as a research primary subject. The selection depends on two criteria. The first criterion of roadkill quantity has been taken for consideration. The species with the highest roadkill quantities exhibited the most wildlife that prefers using this road to migrate from one place to another. Here, the species with the highest amount of roadkill is filtered out and shortlisted. The following criteria included the most endangered species (PERHILITAN, 2018). Among the shortlisted of the highest-ranking of roadkill's in Table 3, the species is then again chosen and clarified. Thus, the most endangered and extinct species were selected as a research primary subject. The selected species is the primary attention of this research study.

Table 3. The Highest Number of Animal-Vehicle Collision from 2012 to 2017

\begin{tabular}{ccccc}
\hline No & NDX & English Name & Scientific Name & Quantity \\
\hline 1 & Mammals & Wild Boar & Sus scrofa & 265 \\
2 & Mammals & Leopard Cat & Prionailurus bengalensis & Tapirus indicus \\
3 & Mammals & Malayan Tapir & Macaca fascicularis & 68 \\
4 & Mammals & Long-tailed Macaque & 439 \\
5 & Mammals & Common Palm Civet & Paradoxurus hermaphroditus & 418 \\
6 & Reptile & Water Monitor Lizard & Varanus salvator & 742 \\
\hline
\end{tabular}




\subsection{Quantitative Data Analysis}

Wildlife is Malaysia's valuable assets; some species could be found and available only in Malaysia. For example, Malayan Tapir and Malayan Tiger are considered valuable as these animals are originated from Malaysia (WWF, 2018). Hence, if the vehicles hit this nearly extinct species, their values of loss are believed to be more expensive due to the limited quantity of these animals. Furthermore, this threatened species is a favorite target of the poacher. As this animal's carcasses are valuable and have a high demand for illegal wildlife trade. Poachers have infiltrated in Malaysia Forest and plundered its wildlife, including tigers. Malaysia's wildlife is desired in the Asian market for use as folk medicine and as a sign of wealth (WWF, 2018).

This process only involves the species mainly selected as primary research subjects. It is advisable for the value of the species is compared according to their standard maximum fine stated in Malaysia Act 716, 2010 (Government of Malaysia, 2010). At the end of this process, the total value of the loss is the total of the roadkill's of selected species multiply by the per-unit price of the species (PERHILITAN, 2018).

\subsection{Value of Killed Wildlife in Ringgit Malaysia (RM)}

The selection of one species and their number of collisions were determined in the value of monies, Ringgit Malaysia (RM). The application of an ecosystem valuation concept (Australian Government, 2010). Here, this concept valued the ecosystem in monetary value (Australian Government, 2010). For example, a recent study by the Western Transportation Institute calculated the average total costs associated with an animal-vehicle collision for three species: $\$ 7,890$ per collision for deer, $\$ 17,100$ for elk and $\$ 28,100$ for moose (Trombulak and Frissell, 2000; Huijser et al., 2009). The animal-vehicle collision is a lesson learned for people and young generation to appreciate the ecosystem services.

\subsection{The Approximate Distance between the Wildlife Roadkill Location and Eco-viaduct}

The quantitative analysis for this research was inducted to evaluate the existence of the eco-viaduct at the roadkill location of the selected wildlife dedicated as research primary subject. Here, a simple calculation was done to determine the approximate distance in kilometre between the eco-viaduct and the primary subject's roadkill locations. Here, Equation 1 is a basic trigonometry formula in getting the approximate distance between the eco-viaducts and the roadkill locations. In the wildlife roadkill data and list of eco-viaducts provided by PERHILITAN, all locations are given in grid coordinates with the result in metre $(\mathrm{m})$ (PERHILITAN, 2018). This formula is divided by one thousand for unit conversion in kilometre $(\mathrm{km})$. The data of the wildlife roadkill shows that these animals did not pass by the ecoviaduct. This calculation is purposely to determine locations that need eco-viaduct or animal crossings when the distance was found to be too far for migration. After the total locations were acquired, the cost-benefit analysis for the eco-viaduct is calculated.

$$
\text { Dis tance }=\frac{\sqrt{\left(x_{2}-x_{1}\right)^{2}}+\sqrt{\left(y_{2}-y_{1}\right)^{2}}}{1000}
$$

\subsection{Results and Discussion}

In the selection of primary research subject, Table 1 indicated the species with the highest amount of roadkill would be filtered out and shortlisted. Among the shortlisted of the highest-ranking of roadkill's, one species is choose based on second criteria, the most endangered species (PERHILITAN, 2018). Based on Table 2, there are six (6) animals that considered the highest species being killed in roadkill from the year 2012 to 2017. According to PERHILITAN, Malayan Tapir is the most endangered and extinct species in recent times. Malayan Tapir is a fully protected wildlife in Malaysia (Government of Malaysia, 2010). Thus, to fulfill the second criteria, Malayan Tapir (Tapirus Indicus) has been selected as the primary research subject (PERHILITAN, 2018).

\subsection{The value of the killed wildlife in Ringgit Malaysia (RM)}

The value of the killed wildlife can be calculated in Ringgit Malaysia (RM) for each species for losses due to animals-vehicle collision (PERHILITAN, 2018). In this paper, Malayan Tapir's value of life was based on the maximum fine stated in Malaysia (Government of Malaysia, 2010). It can be considered that; wildlife species are precious. Therefore, this animal has become a victim of the illegal trafficking business. This wildlife sometimes not sold in one full item, but their body parts were sold separately (Brown, 2017). It has been revealed that Malaysia has become one of the transit points for illegal wildlife trade before heading elsewhere in Asia (Brown, 2017).

Based on the maximum fine, the life value of Malayan Tapir is RM100,000 per unit (PERHILITAN, 2018). The total value of the loss is the total of the roadkill's of selected species multiply by the per-unit price of the species. As a result, the total value of the loss is sixtyeight (68) Malayan Tapir roadkill's multiply by RM100,000 per unit price gives the total loss of RM6,800,000 or RM6.8 million in 5 years. It can be stated that the Laws of Malaysia International Trade in Endangered Species Act 686 and Wildlife Conservation Act 716 are the two (2) prevailing laws related to wildlife (Government of Malaysia, 2010). Most of the fine stated in this Acts is one hundred thousand 
ringgits. That amount is higher than the price of a unit asset, which is reasonable for any wildlife misconduct (Government of Malaysia, 2010).

\subsection{Result from the Approximate Distance between the Wildlife Roadkill Location and Eco-viaduct}

Malayan Tapir is on the brink of extinction, being a victim in the roadkill has worsened the problem. The quantities of sixty-eight (68) Malayan Tapirs killed to prove that these species prefer to use the road for crossing. From this result, we can evaluate the distance of the eco-viaduct where the roadkill happened. The distance between the roadkill location and nearest eco-viaduct calculated was using Equation 1.

From the results obtained, for the nearest distance of roadkill with eco-viaduct for every 68 Malayan Tapirs killed, Terengganu, which owns three eco-viaducts, has the highest Malayan Tapir road killed. Pahang, which owns three eco-viaducts, is the second rank of the most road-killed of Malayan Tapir. Negeri Sembilan owns two eco-viaducts is in the third rank. The first three are the states that have more than one eco-viaduct, but the roadkill still happened. The last three are Johor, Kelantan and Selangor, the states that do not have eco-viaducts with average Malayan Tapir road killed. Pahang is the longest distance between the roadkill locations and the nearest ecoviaduct $(208.07 \mathrm{~km})$, and Negeri Sembilan is the shortest one. The results were not disclosed herein in the research paper.

However, Table 4 shows the simplified version of the Malayan Tapir road-killed in the states that have eco-viaducts. Terengganu, Pahang, and Negeri Sembilan. The average amount of Malayan Tapir road-killed found in the states that do not have eco-viaducts, Johor, Kelantan, and Terengganu. The states that have eco-viaducts need to have improvement plans to reduce the roadkill numbers. Meanwhile, the states that do not have the eco-viaduct may need to consider constructing a new eco-viaduct. The shortest distance found in Negeri Sembilan approximately $15.29 \mathrm{~km}$ and the longest one in Pahang, which is about $208.07 \mathrm{~km}$. It can be observed that Malayan Tapir average distance to travel as far as $88.78 \mathrm{~km}$ per month.

The shortest distance may be related to eco-viaduct effectiveness. Due to the lack of efficiency of these wildlife crossings, those animals did not feel attracted to use it. The roadkill happens at Kg Bukit Tangga, Kuala Pilah, Negeri Sembilan, and the nearest ecoviaducts were at Seremban, 37.3m Height Overpass (result not shown here). Improvement needs to be done on the design, and the tropical forest elements should be added more for this case. An improvement needed for the crossing structure or eco-viaduct, i.e., landscape maintenance, plants, salt licks and added fence. The research on wildlife behavior is recommended to identify the needs and majority of species living in this place.

Table 4 Malayan Tapirs Roadkill Range of Distances by State

\begin{tabular}{cccccc}
\hline No & State & Roadkill & $\begin{array}{c}\text { Range of Approximate } \\
\text { Distance }(\mathrm{km})\end{array}$ & No. of ecoviaduct & $\begin{array}{c}\text { Value of Loss } \\
\text { (RM100,000 per unit) (Act } \\
\text { (A16, 2010) }\end{array}$ \\
\hline 1 & & & & $3,000,000$ \\
2 & Terengganu & 30 & $38.71-135.14$ & 3 & $1,300,000$ \\
3 & Pahang & 13 & $139.62-208.07$ & 3 & 600,000 \\
4 & N. Sembilan & 6 & $15.29-45.04$ & 2 & $1,300,000$ \\
5 & Johor & 13 & N/A & No ecoviaduct & 400,000 \\
6 & Kelantan & 4 & N/A & No ecoviaduct & 200,000 \\
\hline & Selangor & 2 & N/A & No ecoviaduct & RM6,800,000 \\
\hline
\end{tabular}

\subsection{Parameter of Consideration}

Salt lick is used to attract the animals towards the eco-viaduct instead of using the road or highways for crossing. There are ten salt licks provided. The salt that is used is the same type used for cooking (PERHILITAN, 2016). Based on (Magintan et al., 2015), the definition of salt lick refers to any mineral spring or ground containing salt or any other mineral of which the consumption is conducive to the health or well-being of wildlife (Government of Malaysia, 2010; Magintan et al., 2015). Several preliminary observation of salt licks has been done with a total of 30 salt licks recorded at the protected area developed from the year 2011 to 2012 (Magintan et al., 2015).

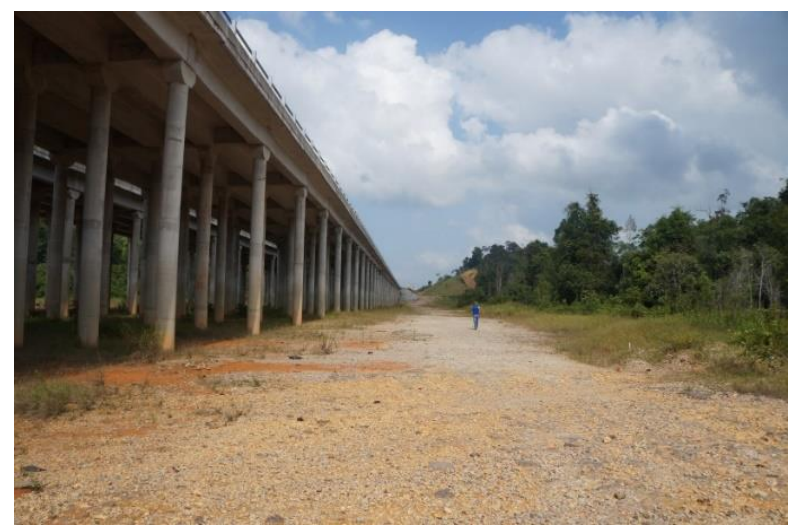

Fig. 1: A photo of post-construction at East Coast Highway Underpass (Source: PERHILITAN, 2018) 
A $20 \mathrm{~km}$ electrical fence has been installed along the way to block the animals from crossing the road. As for now, no animals reported dead due to the electrical fence (Kamarul Zaman, 2013). Several parameters for consideration on minimizing the wildlife roadkill are to have a lookout tower. Here, the function of a lookout tower is to monitor wildlife movement that passes through and within the area. Most of this lookout tower was built at the end of the eco-viaduct (Kamarul Zaman, 2013). However, frequent surveillance is needed in this facility to observe the animal's migration. Figure 1 showed the post-construction of East Coast Highway Underpass, and much need to be done to attract the animals for using this eco-viaduct.

More advanced technology, such as using a camera, is one of the options to reduce animal-vehicle collision. These cameras were installed in a few points at the eco-viaduct to help in collecting data, recordings, and monitoring the species that used the eco-viaduct (Kamarul Zaman, 2013). Landscape at eco-viaduct was planted with Trema Angustifolia and Napier grass as the main attraction for the wildlife to move towards the eco-viaduct. The plants are the main dish for wildlife, such as elephants and deer's (Kamarul Zaman, 2013).

In the United States of America (USA) and European countries (Slovenia, Switzerland, Germany, France, and the Netherlands) are much more advanced in mitigating wildlife issues (see Figure 2). There are several kinds of research done in improving the design of wildlife crossings (Rytwinski et al., 2015). Some mitigation measures include animal detection systems, wildlife warning signs, changes in road-verge management, measures to reduce traffic volume, speed and noise. Several alleviations such as temporary road closure, wildlife crossing structures, wildlife fences (e.g., barrier fencing or exclusion fencing) can be considered.

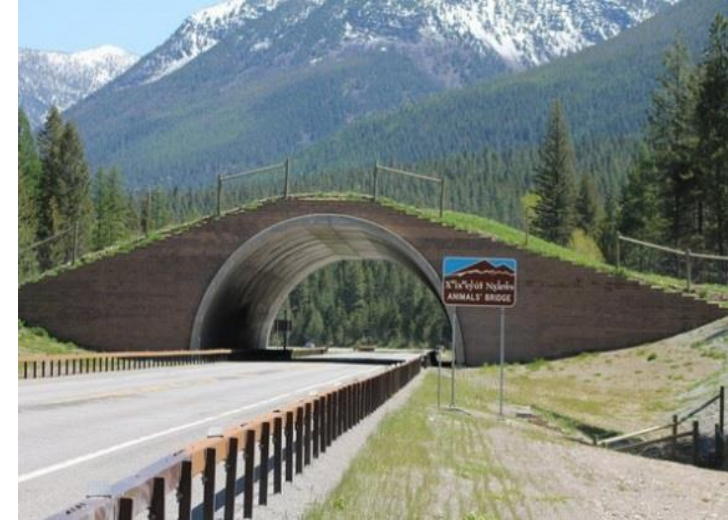

(a)

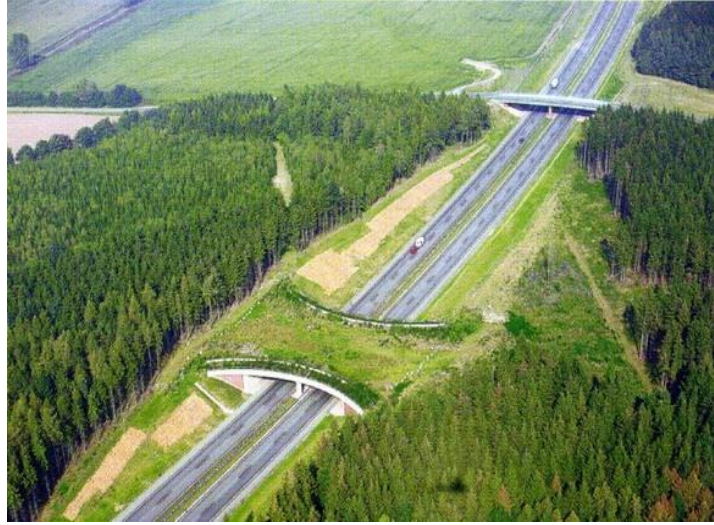

(b)

Fig. 2: (a) The animal bridge, USA; (b) The green bridge, Germany (Source: Rytwinski et al., 2015)

Some of the methods are used to prevent wildlife from assessing the road which used funnel fencing that is built along with the wildlife crossing structures and avoid the wildlife from assessing the road. Hence, the wildlife reflectors, wildlife repellents and modified road designs for eco-viaducts and lighting is installed in bridges were also an approach to prevent the wildlife from crossing the road (Ford et al., 2010; Huijser et al., 2009)

This wildlife crossing structure (e.g., under or overpasses: amphibian tunnels, badger pipes, ledges in culverts, land bridges, rope bridges, glider, poles) combined with fencing to prevent mortality and funnel wildlife towards the crossing structures. This structure has gained considerable attention from transportation agencies (Van der Grift et al., 2013). Green landscapes and vegetation also need to be embedded in this crossing structure to attract wildlife in using this facility.

\subsection{Conclusion}

In conclusion, it can be observed from the research study an amount of sixty-eight (68) Malayan Tapir (as the primary research subject) has been killed due to vehicle collision in Peninsular Malaysia from the year 2012 to 2017. This Malayan Tapir's value of life is RM100,000 per unit price, given the total loss of RM6,800,000 or RM6.8million in 5 years. It can be noticed that several parameters need to be considered when building a wildlife crossing. This structure of eco-viaduct or eco-bridge can be designed creatively and more sustainable to suit requirement and necessities of the wildlife. Furthermore, several methods and mitigation measures to stabilize their ecology, nature and habitat need to be implemented. However, there are several recommendations to further extend the research in wildlife behavior. This task would take a lot of work and effort as it is essential to conserve our wildlife. Better understandings in wildlife behavior and necessities are needed as the appropriate design of the eco-viaduct can be established to suit the purpose of this structure.

\section{Acknowledgements}

The authors gratefully acknowledged PERHILITAN for providing the raw data for the animal roadkill. They gratefully acknowledged Universiti Teknologi MARA, Shah Alam, by providing the research grant (600-IRMI 5/3/GIP (018/2019)) and financially supported this research study. 


\section{References}

Ahmad Zafir, A.W., \& Magintan, D. (2016). Historical review of human-elephant conflict in Peninsular Malaysia. Journal of Wildlife and Parks, 31 , 1-19.

Australian Government. (2010). Ecosystem Services: Key Concept and Applications. Retrieved from http://www.environment.gov.au/system/files/resources/b53e60024ea7-4108-acc8-40fff488bab7/files/ecosystem-services.pdf.

Brown, V. (2017). Traffic: Malaysia is a key point in the illegal wildlife trade. Malaysia. Retrieved from https://www.thestar.com.my/news/nation/2017/04/11/malaysia-keytransit-point-for-wildlife-trade/

Coffin A.W. (2007). From roadkill to road ecology: A review of the ecological effects of roads. Journal of Transport Geography, 15, 396-406.

DURA Technology Sdn Bhd. (2014). Dura Viaduct to Free the Elephants from Accidents. Retrieved from http://dura.com.my/completed-projects/2015-project/151-duraviaduct-to-free-the-elephants-from-collions.

Fayle, T. T. (2015). Whole - ecosystem experimental manipulations of tropical forests. Trend in Ecology and Evolution, 30(6), 334-346.

Ford, A. C. (2010). Comparison of Methods of Monitoring Wildlife Crossing-Structures on Highways. Journal of Wildlife Management, 73(7), $1213-1222$.

Government of Malaysia. (2010). Laws of Malaysia, Wildlife Conservation 2010, Act 716.

Huijser, M. D. (2009). Cost-Benefit Analyses of Mitigation Measures Aimed at Reducing Collisions with Large Ungulates in the United States and Canada: A Decision Support Tool. Ecology and Society, 14(2), 1-15.

Jacobson, S. B. K. (2016). A behavior-based framework for assessing barrier effects to wildlife from vehicle traffic volume. Ecosphere, 7(4), 1-15.

JKR. (2015). Project Summary, Central Spine Road, Package 3, Gua Musang Kelantan to Kampung Relong, Pahang, 3F1, 3F2, 3G, 3H. Kampung Kubang Rusa to Kampung Kechur.

Kamarul Zaman, K. (2013). Jambatan Tanpa Sungai (Bridge without a river).

Magintan, D. I. (2015). A Preliminary Observation of Mammals and Other Species Visiting Artificial Salt Licks In Peninsular Malaysia. Journal of Wildlife and Parks, 30, 59-74.

PERHILITAN. (2016). Wildlife Annual Report. Retrieved from http://www.wildlife.gov.my/images/document/penerbitan/laporantahunan/LP2016\%20-\%2020022018.pdf

PERHILITAN. (2018). Standard Asset Value of Life version June 5.

Pradhan, P. C. (2017). A Systematic Study of Sustainable Development Goal (SDG) Interactions. Earth's Future, 5(11), $1169-1179$.

Rytwinski, T. V. (2015). Experimental study designs to improve the evaluation of road mitigation measures for wildlife. Journal of Environmental Management, 154, 4864.

Sodhi, N. K. (2010). Conserving Southeast Asian forest biodiversity in human-modified landscapes. Biological Conservation, 143(10), 2375-2384.

Trombulak, S., \& Frissell, C. (2000). Review of Ecological Effects of Road on Terrestrial and Aquatic Communities. Retrieved from https://defenders.org/sites/default/files/publications/getting_up_to_speed_natural_environment.pdf.

UNDP. (2013). Improving Connectivity in the Central Forest Spine (CFS) Landscape - IC-CFS Project Document. United Nations Development Program (UNDP), Malaysia, Global Environment Facility (GEF).

Van der Grift, E. V. (2013). Evaluating the effectiveness of road mitigation measures. Biodiversity and Conservation, 22, $425-448$.

WWF. (2018). Malayan Tiger and Malayan Tapir. Retrieved from https://www.worldwildlife.org/species/malayan-tiger. 